\title{
Increased expression of growth factor genes for macrophages and fibroblasts in bronchoalveolar lavage cells of a patient with pulmonary histiocytosis $\mathrm{X}$
}

\author{
J Barth, H Kreipe, H J Radzun, K Heidorn, W Petermann, B Bewig, M R Parwaresch
}

\begin{abstract}
Pulmonary histiocytosis $X$ is the local manifestation of a systemic disorder of unknown cause characterised by infiltration of Langerhans cell like histiocytes and parenchymal fibrosis. In a male smoker with histologically proved histiocytosis $X$ and functional impairment bronchoalveolar lavage showed an increase in CD-1/OKT-6 antigen positive histiocytes to $8 \%$. Northern blot analysis of RNA from bronchoalveolar lavage cells showed an exaggerated expression of the M-CSF gene and of the c-fms gene encoding for the corresponding receptor. An increased level of c-sis RNA, which encodes the $B$ chain of platelet derived growth factor, was also found. Diffuse reticulonodular infiltrates on the chest radiograph resolved with glucocorticoid treatment and CD-1/OKT-6 antigen positive histiocytes fell to $3 \%$. Macrophage colony stimulating factor, c-fms and c-sis gene expression were reduced almost to normal after treatment. The results suggest that macrophage colony stimulating factor and platelet derived growth factor may have a role in the initiation or maintenance of pathological reactions in pulmonary histiocytosis $\mathbf{X}$.
\end{abstract}

Pulmonary histiocytosis $\mathrm{X}$ is an idiopathic interstitial lung disease characterised by infiltrating Langerhans like histiocytes and eosinophils. ${ }^{15}$ In most cases pulmonary infiltrates resolve with minimal or no residual fibrosis, though a few patients may progress to end stage pulmonary fibrosis. The underlying immunological mechanisms are not known and why some cases progress to severe fibrosis is not clear. Lesions are characterised by proliferation of two major cellular constituents, histiocytes and fibroblasts. Proliferation and activation of both cell types are regulated by soluble growth factors that have been identified and characterised. ${ }^{48131418}$ The B chain of the fibroblast mitogen, platelet derived growth factor is encoded by the c-sis proto-oncogene. ${ }^{2}$ Bronchoalveolar lavage cells of a patient with pulmonary histiocytosis $\mathrm{X}$ were analysed for the expression of the gene for this potent fibroblast growth factor and of the genes for haematopoietic growth factors, which increase proliferation and activation of macrophages and macrophage related cells. ${ }^{813}$ In addition, we analysed RNA expression of interleukin-3, granulocyte-macrophage colony stimulating factor (GM-CSF), macrophage colony stimulating factor (M-CSF) and of cfms that encodes for the M-CSF receptor.

\section{Methods}

Bronchoalveolar lavage was performed with $200 \mathrm{ml}$ sterile physiological saline. For immunophenotyping of lavage cells and tissue specimens the monoclonal antibodies OKT-6 and S-100 (Ortho, Heidelberg) were used. The immunostaining procedures were performed as described previously.

\section{Northern blot analysis}

Total cellular RNA was purified under ribonuclease inactivating conditions by the guanidine thiocyanate-caesium chloride method and analysed by electrophoresis of $10 \mu \mathrm{g}$ RNA through $1 \cdot 2 \%$ agarose formaldehyde gels followed by Northern blot transfer to coated nylon membranes (Genescreen, New England Nuclear, Boston, Massachusetts. ${ }^{11}$ The cloned v-fms gene pSM3 was a gift from Dr C J Sherr, Memphis, Tennessee..$^{5}$ A 1036 bp BgII/PstI fragment of the human M-CSF gene pcCSF-17 was obtained from Cetus Corporation, Emeryville, California. ${ }^{9}$ The cloned human GM-CSF gene and the gibbon interleukin-3 gene were obtained from the Genetics Institute, Cambridge, Massachusetts. ${ }^{1718}$ The integrity of the RNA samples was checked by hybridisation with the cloned actin gene obtained as a gift from $\mathrm{Dr}$ $M$ W Kirschner, San Francisco. ${ }^{3}$

DNA probes were labelled with ${ }^{32} \mathrm{P}$ deoxycytidine triphosphate $(3000 \mathrm{Ci} / \mathrm{mmol}$; Amersham, Braunschweig, Germany) by oligonucleotide priming (Multiprime, Amersham, Braunschweig) to specific radioactivities of $1.5 \times 10^{9}-3 \times 10^{9} \mathrm{cpm} / \mu \mathrm{g} \mathrm{DNA} .^{6} \mathrm{Mem}-$ branes were prehybridised at $42^{\circ} \mathrm{C}$ for 24 hours in buffer consisting of $50 \%$ formamide, $5 \times$ sodium chloride sodium citrate (SSC), $1 \%$ sodium dodecyl sulphate (SDS), $2 \times$ Denhardt's solution, $25 \mathrm{mM}$ phosphate buffer (pH 7.0 ), $5 \%$ dextran, and $200 \mu \mathrm{g} / \mathrm{ml}$ salmon 
Figure 1 Chest radiographs ( $a$ ) at the time of presentation, displaying a reticulonodular pattern and (b) after three months' treatment with corticosteroids, showing a considerable improvement.
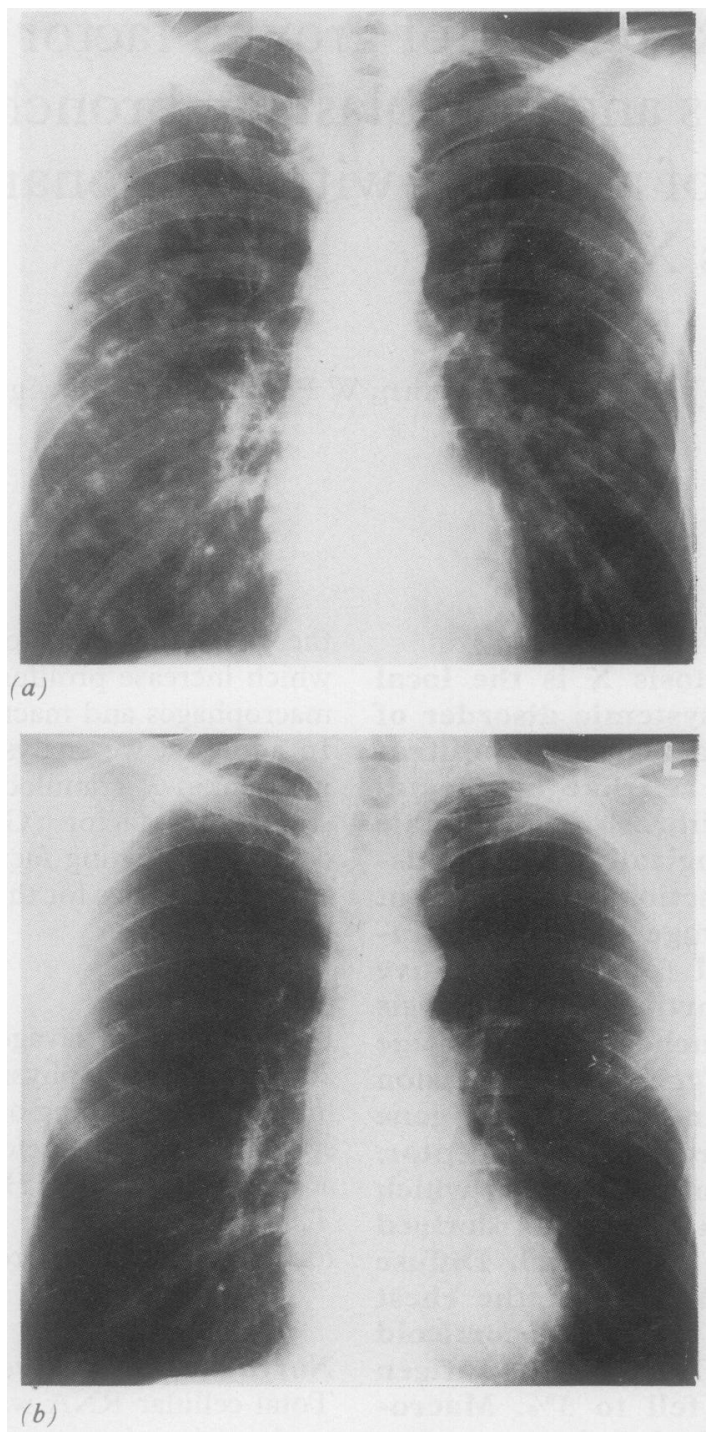

sperm DNA. The RNA blots were hybridised for $24-48$ hours at $42^{\circ} \mathrm{C}$ with $1 \times 10^{7} \mathrm{cpm}$ labelled DNA probe/ml hybridisation buffer (the same as prehybridisation buffer). After hybridisation the blots were washed twice in $2 \times$ SSC and $0.5 \%$ SDS for five minutes at room temperature, twice in $0.2 \times$ SSC and $0.5 \%$ SDS for five minutes, and twice in $0.1 \times$ SSC and $0.5 \%$ SDS for 30 minutes at $55^{\circ} \mathrm{C}$. After drying blots were exposed to $x$ ray films (Kodak XAR 5) with an intensifying screen at $-70^{\circ} \mathrm{C}$ for up to seven days.

\section{Case report}

A 43 year old man was admitted to hospital with fever, cough, and chest pain of three months' duration. He smoked 30 cigarettes a day but had not been exposed to any.inhalation hazards. Physical examination showed.. no abnormalities. Investigations revealed a raised erythrocyte sedimentation rate and mild neutrophilia with $6 \%$ unsegmented neutrophils, $1 \%$ myelocytes, and $14 \%$ monocytes. Screening for various viruses including human immunodeficiency virus, gave negative results. A chest radiograph showed bilateral reticulonodular infiltrates (fig $1 a$ ) with a pneumothorax at the apex of the right lung. Lung function tests showed a decrease of vital capacity to $73 \%$ predicted. Single breath transfer factor for carbon monoxide (TLCO) was $65 \%$ predicted. Cytological examination of bronchoalveolar lavage fluid showed $93 \%$ macrophages, most laden with brown pigment, $6 \%$ lymphocytes, and $1 \%$ granulocytes. The proportion of CD1/OKT-6 positive histiocytes was $8 \%$. Examination of the transbronchial biopsy specimens led to the diagnosis of an interstitial lung fibrosis of uncertain aetiology. Morphological changes typical of histiocytosis $\mathrm{X}$ were found in an open lung biopsy specimen (fig 2). The disease appeared to be restricted to the lung as other investigations, including scintillation scanning of the bones, yielded negative results. Glucocorticoid treatment was started with prednisolone $80 \mathrm{mg} /$ day, leading to rapid disappearance of his symptoms. After three months the infiltrates in the chest radiograph had almost resolved except for slight residual reticulation (fig $1 b$ ). Vital capacity and TLCo had improved considerably to values close to normal. Cytological examination of lavage fluid at this time showed $94 \%$ alveolar macrophages, $5 \%$ lymphocytes, and $1 \%$ granulocytes. Only $3 \%$ of CD-1/OKT -6 positive cells could be seen. After a further three months repeat investigations gave almost identical results.

\section{Northern blot analysis of growth factor genes}

These clinical findings were associated with changes in the level of macrophage activation and profibrotic gene expression. The level of cfms transcripts that code for the M-CSF receptor was high during the acute phase of the disease, and fell after glucocorticoid treatment (fig 3). At this stage the amount of detectable fms-transcripts in alveolar macrophages were similar to that in normal alveolar macrophages. The exaggerated level of $c-f m s$ gene expression was accompanied by an enhanced autostimulatory expression of the M-CSF gene (fig 3). RNA of other haemopoietic growth factor genes, such as GM-CSF and Interleukin-3, were not detected in lavage fluid cells, either during the acute phase or after resolution of the radiographic infiltrates. At the onset of the disease the level of c-sis gene expression by histiocytosis X lavage cells was high, and fell after three months' of glucocorticoid treatment (fig 3).

Thus lavaged cells obtained during the acute phase of the disease showed enhanced expression of the M-CSF gene, its corresponding receptor gene, and the c-sis gene; all returned to normal levels after resolution of the pulmonary infiltrates.

\section{Discussion}

Cell to cell interaction in immunological responses are mediated by soluble regulatory factors. Several such factors are produced by monocytes and macrophages, which appear to have a central role in the inflammation and tissue repair by controlling angiogenesis and fibroblast proliferation. An important factor is 
Figure 2 (a) Open lung biopsy specimen showing severe interstitial inflammation with fibrotic obliteration of the alveolar spaces. The inflammatory infiltrate consisted of eosinophilic granulocytes, mononuclear cells, and many histiocytes with indented, reniform nuclei, resembling Langerhans cells. (Haematoxylin and eosin.) (b) Immunohistochemically they display the $S-100$ antigen in their cytoplasma, confirming that they were histiocytosis $X$ cells.

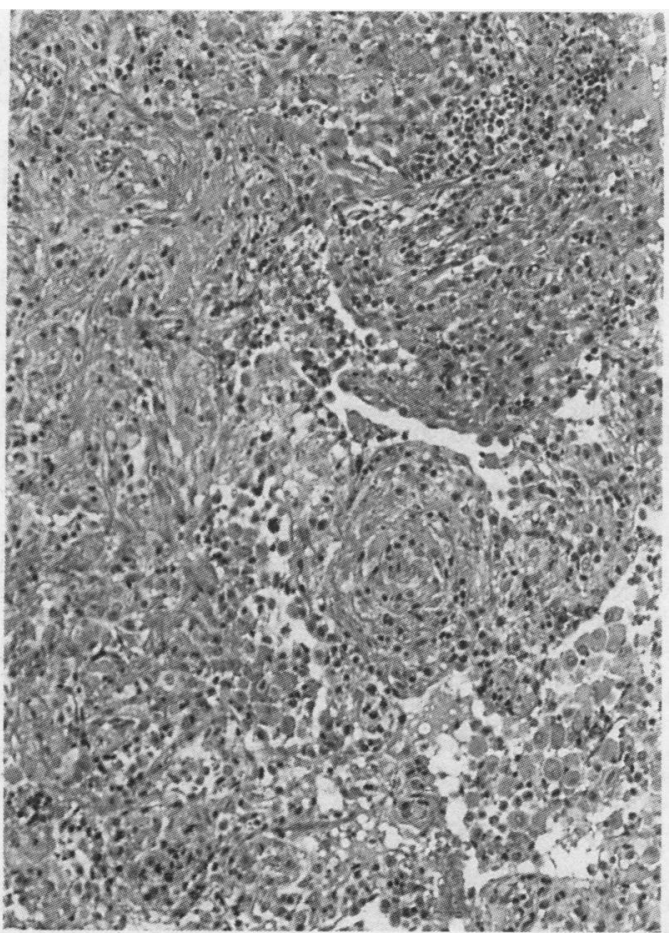

(a)

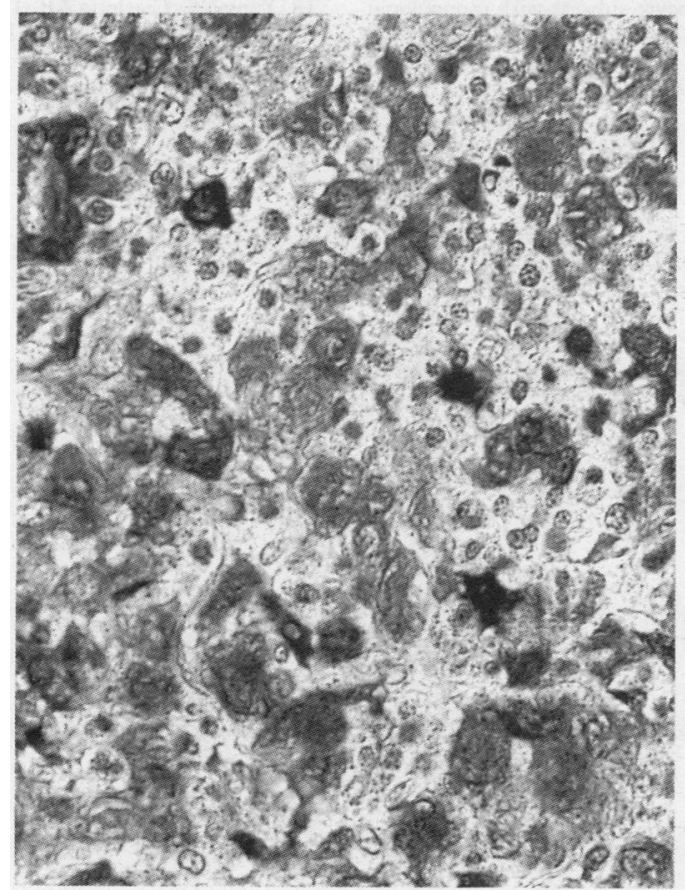

(b)

platelet derived growth factor, a potent mitogen for fibroblasts, ${ }^{4}$, which is in part encoded by the c-sis proto-oncogene. ${ }^{2}$ Normal alveolar macrophages constitutively express. low levels of the c-sis gene..$^{12}$ Our results show that in the proliferative phase of pulmonary histiocytosis $\mathrm{X}$, when fibrotic activity would be expected, more transcripts of the c-sis gene were found in lavage fluid cells (fig 3), suggesting a role for c-sis in the induction of fibrotic processes in this condition. . This is supported by reports of an exaggerated spontaneous release of platelet derived growth factor by alveolar macrophages in idiopathic pulmonary fibrosis. ${ }^{12}$
The exact cellular source of c-sis remains questionable in this case and it is not clear whether it could be ascribed to the CD-1/ OKT-6-positive histiocytes or to stimulated macrophages. In addition to the c-sis expression we analysed both the expression of the $M$ CSF gene and the gene for the corresponding $\mathrm{M}-\mathrm{CSF}$ receptor encoded by the c-fms gene. As previously described in active pulmonary sarcoidosis, ${ }^{11}$ the acute phase of histiocytosis $\mathrm{X}$ was characterised by a higher level of c-fms gene expression by lavage cells (fig 3 ), which is ascribed to an increased influx of immature macrophage precursors into the alveoli. ${ }^{111}$

Normal alveolar macrophages display a low level of c-fms expression, ${ }^{11}$ and activation of monocyte-macrophages is accompanied by a reduced expression of the c-fms gene. ${ }^{10}$

Contaminating lymphocytes in the lavage fluid are considered unlikely to have been responsible for the increased level of $\mathrm{M}$-CSF gene transcripts as they made up only $6 \%$ of all cells.

With the resolution of pulmonary infiltrates caused by corticosteroid treatment $\mathrm{M}-\mathrm{CSF}$ gene expression returned to normal levels (fig 3). ${ }^{11}$ We conclude that autostimulation of monocyte/macrophages via M-CSF may represent a central component of the abnormal

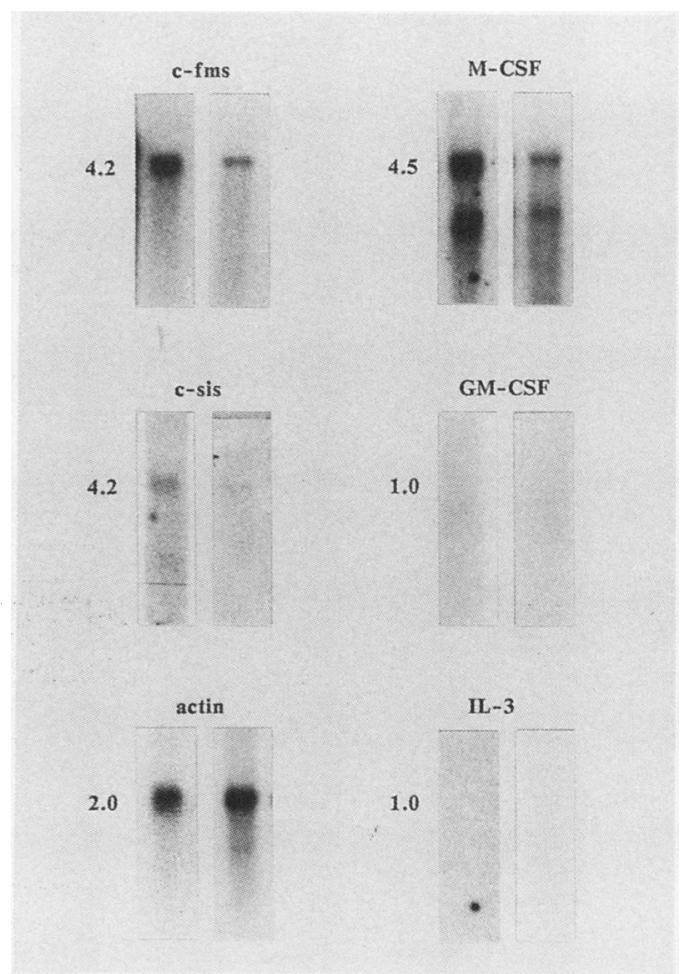

Figure 3 Northern blot analysis of lavage fluid cells, showing that the expression of the c-fms, c-sis, and MCSF genes changes during the course of histiocytosis $X$. In the acute phase (left lane) high levels of the c-fms gene and the M-CSF gene were detected: the expression of both genes returned to normal" after resolution of the pulmonary infiltrates (right lane). The hybridisation with an actin gene showed that equal amounts of intact $R N A$ have been blotted. In addition, lavage fuid cells at presentation had a higher level of expression of the c-sis proto-oncogene, which codes for the B chain of platelet derived growth factor. Transcripts of GM-CSF or the interleukin-3 gene were not found either in the acute phase of histiocytosis $X$ or after resolution of the infiltrates. 
immunological reaction in pulmonary histiocytosis $\mathrm{X}$ as $\mathrm{M}-\mathrm{CSF}$ is known to induce various relevant inflammatory mechanisms in monocyte-macrophage populations. ${ }^{16}$

This study was supported by Bundesministerium für Forschung und Technologie grant OI KE 8813.

1 Barth J, Kreipe H, Kiemle-Kallee J, Radzun HJ, Parwaresch MR, Petermann W. Diminished activity of tartrate resistant acid phosphatase in alveolar macrophages from patients with active arcoidosis. Thorax 1988;43:901-4.

2 Chiu IM, Reddy EP, Givol D, Robbins KC, Tronick SR, Aaronson SA. Nucleotide sequence analysis identifies the human c-sis protooncogene as a structural gene for platelet-derived growth factor. Cell 1984;37:123-9.

3 Cleveland DW, Lopata MA, MacDonald RJ, Cowan NJ, Rutter WJ, Kirschner MW. Number and evolutionary conservation of $\alpha$-and $\beta$-tubulin and cytoplasmic $\beta$ and $\gamma$ actin genes using specific cloned cDNA probes. Cell 1980;20:90-105.

4 Deuel TF, Huang JS. Platelet-derived growth factor. Structure, function, and roles in normal and transformed cells. Clin Invest 1984;74:669-76.

5 Donner L, Federle LA, Garon CF, Anderson SJ, Sherr CJ. $\mathrm{McDonough}$ feline sarcoma virus: characterization of the molecularly cloned provirus and its feline oncogene ( $v$ fms). $J$ Virol 1982;41:489-500.

6 Feinberg AP, Vogelstein B. A technique for radiolabeling DNA restriction endonuclease fragments to high specific activity. Analyt Biochem 1983;132:6-13.

7 Feller AC, Parwaresch MR, Wacker HH, Radzun HJ, Lennert $\mathrm{K}$. Combined immunohistochemical staining for surface IgD and T-lymphocyte subsets with monoclonal antibodies in human tonsils. Histochem $J 1983 ; 15: 557-62$.

8 Griffin JD. Hemopoietins in oncology: factoring out myelosuppression. J Clin Oncol 1989;7:151-5.
9 Kawasaki ES, Ladner MB, Wang AM, Van Arsdell J, Warren MK, Coyne MY, et al. Molecular cloning of a complementary DNA encoding human macrophagespecific colony-stimulating factor (CSF-1). Science 1985;230:291-6.

10 Kreipe H, Radzun HJ, Rudolph P, Barth J, Hansmann ML, Heidorn $\mathrm{K}$, et al. Multinucleated giant cells generated in vitro. Terminally differentiated macrophages with downregulated c-fms expression. Am J Pathol 1988;130: 232-43.

11 Kreipe H, Radzun HJ, Heidorn K, Barth J, Kiemle-Kalle J, Petermann W, et al. Proliferation, macrophage-colonystimulating factor and macrophage colony-stimulating factor-receptor expression of alveolar macrophages in active sarcoidosis. Lab Invest 1990;62:697-703.

12 Martinet Y, Rom WN, Grotendorst GR, Martin GR, Crystal RG. Exaggerated spontaneous release of plateletderived growth factor by alveolar macrophages from patients with idiopathic pulmonary fibrosis. $N$ Engl J Med 1987;317:202-9.

13 Metcalf $D$. The molecular biology and functions of the granulocyte-macrophage colony stimulating factors. Blood 1986;67:257-63.

14 Rambaldi A, Young DC, Griffin JD. Expression of the MCSF (CSF-1) gene by human monocytes. Blood 1987;69:1409-13.

15 Rosenow EC. Primary pulmonary histiocytosis X. In: Fishman AP, ed. Pulmonary diseases and disorders. Vol 1.2nd ed. New York: McGraw-Hill, 1988:813-8.

16 Warren MK, Ralph P. Macrophage growth factor CSF-1 stimulates human monocyte production of interferon, tumor necrosis factor, and colony stimulating activity. $J$ Immunol 1986;137:2281-5.

17 Wong GG, Witek J, Temple PA, Wilkens KM, Leary AC Luxenberg DP, et al. Human GM-CSF: molecular cloning of the complementary DNA and purification of the natural and recombinant proteins. Science 1985;228: $810-5$.

18 Yang YC, Ciarletta AB, Temple PA, Chung MP, Kovacic S, Witek J, et al. Human IL-3 (Multi-CSF): identification by expression cloning of a novel hematopoietic growth factor related to murine IL-3. Cell 1986;47:3-10. 